Table 1

\begin{tabular}{|c|c|c|c|c|c|c|c|c|c|}
\hline \multirow[b]{2}{*}{ Patient } & \multicolumn{4}{|c|}{ Transfusion data } & \multicolumn{4}{|c|}{ Factor VIII activity } & \multirow{2}{*}{$\begin{array}{l}\text { Skin bleeding } \\
\text { time } 10 \text { min } \\
\text { after } \\
\text { transfusion } \\
\text { (min) }\end{array}$} \\
\hline & Material & $\begin{array}{l}\text { Volume } \\
\text { (ml.) }\end{array}$ & $\begin{array}{l}\text { Factor VIII } \\
\text { activity }(a) \\
\text { (ml.) }\end{array}$ & $\begin{array}{l}\text { Duration of } \\
\text { transfusion } \\
\text { (min) }\end{array}$ & $\begin{array}{c}\text { Before } \\
\text { transfusion } \\
(\%)\end{array}$ & $\begin{array}{l}\text { Expected } \\
\text { activity } \\
(b)(\%)\end{array}$ & $\begin{array}{c}\text { Observed } \\
\text { activity } \\
(\%)\end{array}$ & $\begin{array}{l}\text { Time after } \\
\text { transfusion } \\
(\mathrm{h})\end{array}$ & \\
\hline $\begin{array}{c}\text { Von Willebrand's } \\
\text { disease (D. W.) }\end{array}$ & $\begin{array}{l}\text { Plasma }(c) \\
\text { Serum }(d)\end{array}$ & $\begin{array}{l}1,000 \\
1,100\end{array}$ & $\begin{array}{r}1,000 \\
<11\end{array}$ & $\begin{array}{l}37 \\
65\end{array}$ & $\begin{array}{r}14 \\
9\end{array}$ & $\begin{array}{l}33 \\
10\end{array}$ & $\begin{array}{l}62 \\
82\end{array}$ & $\begin{array}{c}4-8 \\
8\end{array}$ & $\begin{array}{r}7 \\
>20\end{array}$ \\
\hline Hæmophilia $A$ & $\begin{array}{l}\text { I- } 0 \text { (e) } \\
\text { Plasma fraction }\end{array}$ & 180 & 540 & 15 & 10 & 27 & 42 & 14 & 12 \\
\hline (R.C.) & $\mathrm{I}-0(f)$ & 700 & 1,800 & 54 & $<1$ & 44 & 35 & 1 & - \\
\hline
\end{tabular}

(a) Expressed as ml. of plasma with 100 per cent normal factor VIII activity. (b) Caiculated on basis of simple mixing. (c) 9 vol. of normal blood added to 1 vol. of a solution containing $0.053 \mathrm{M}$ citric acid and $0.105 \mathrm{M}$ trisodium citrate, plasma obtained by centrifugation and stored at $-20^{\circ} \mathrm{C}$ for 30 days. 'Thawed and warmed to $37^{\circ} \mathrm{C}$ immediately before use (Fig. 1, curve $\mathrm{O}$ ). $($ d $)$ Blood collected without anticoagulant; kept at room temperature for $24 \mathrm{~h}$, centrifuged. serum collected, stored for $24 \mathrm{~h}$ at room temperature and then $24 \mathrm{~h}$ at $2^{\circ} \mathrm{C}$

activity in his plasma and his skin bleoding time is consistently in excess of $20 \mathrm{~min}$, except after blood trans. fusions. His plasma volume is assumed to be 3 litres. He has bec'n transfused successively with plasma, serum and plasma fraction I- 0 (rof. 3). Factor VIII determinations in plasma and skin bleeding time were performed at intervals. The relevant results are shown in Table 1 and Fig. 1 and are compared with that of a patient (R.C.) with severe hæmophilia $A$ (less than 1 per cent plesma factor VIII) whose plasma volume is assumed to bo 3.5 litres. The results after transfusion observed in R. C. are typical of those seen in hrmophilia $A$ in which the half-life of transfused factor VIII is between 5 and $15 \mathrm{~h}$. In the case of $\mathrm{D}$. W. the plasma factor VIII activity rose much higher than expected following transfusion of plasma or serum. In addition the skin bleeding time was shortened after the transfusions of plasma or of the plasma fraction $\mathrm{I}-0$ but the serum transfusion did not shorten the skin bleeding time. Factor VIII activity was assayed by two independent techniques (partial thromboplast in time and thrombo. plastin gereration), using plasma with less than 1 per cent factor VIII from hæmophilia $A$ patients. Nonspecific effects were exchuded. It is believed the results represent true factor VIII-levels.

The observations suggest that normal plasma contains two comporents which are lacking in patients with von Willebrand's syndrome. The component which stimulates factor VIII activity in vivo is present both in eitrated plasma $(p H 7 \cdot 1)$ stored at $-20^{\circ} \mathrm{C}$ for 30 days and in serum. Only a low activity is present in lyophilized plasma fraction I-0. The second component which shortens the bleeding time is present in frozon plasma and plasma fraction $\mathrm{I}-0$, but is absent from serum.

Potentiation of factor VIII activity occurs in normal persons and hæmopl i ic patients with measurable levels of plasma factor VIII immediately after exercise ${ }^{4}$ or adrenaline infusion ${ }^{5}$, and a rise of factor VIII activity occurs in normal persons 1-3 days after serum infusion ${ }^{6}$.

There is no obvious relation between these observations and the reported experiments.

The elinical implications will be reported separately.

We thank tho Red Cross Blood Transfusion Service, Molbourne. for the supply of blood and blood products.

This work was supported by a grant-in-aid from the National Health and Medical Research Council, Canberra.

Baker Medical Research Institute,

$$
\text { P. FantL }
$$
Molbourne.

Department of Hæmatology, Alfred Hospital, Melbourne.

\footnotetext{
${ }^{1}$ Nilsson, I. M., Blombäck, M., and Blombäck, B., Acta Med. Scand., 164 $263(1959)$.

Cornu, P., Larrieu, M. J., Caen, J., and Bernard, J., Nouvelle Rev. Franc. d'Hematologie, 1, 231 (1961)

${ }^{3}$ Blombäck, M., Arkiv. Remi., 12, 387 (1958). (The material was supplied in dry form by the Commonwealth Serum Laboratories, Melbourne.) 4 Rizza, C. R., J. Physiol., 156, 128 (1961).

Ingram, G. I. C., J. Physiol., 156, 217 (1961).

${ }^{6}$ Egeberg, O., Scand. J. Clin. Lab. Invest., 14, 475 (1962).
}

\section{Correlation between Rheumatic Diseases and Rh Blood Groups}

WE have recently determined the blood groups of 99 patients with some variety of articular disease (31 with rheumatoid arthritis, 31 with rheumatoid spondylitis, 15 with gout, 9 with disseminated lupus erythematosus, 6 with familial Mediterranean fever, and 7 with various other diseases). Statistical analyses demonstrated no significant heterogeneity among the results obtained for the different diseases. Accordingly, the data were pooled. For comparison we used Wiener's series of 1071 New York Whites ${ }^{1}$, as in a previous investigation ${ }^{2}$. There is a significant correlation between the absence of the Rh antigen $D$ and rheumatic disease, as shown in Table 1. No correlation was found between the presence of rheumatic disease and antigens $\mathrm{C}$ or $\mathrm{E}$, or with the ABO blood group system. There did, however, seem to be a correlation with the absence of antigen $\mathrm{N}\left(\chi_{12}^{2},=9.59, P=8 \times 10^{-3}\right)$.

$$
\begin{array}{lccr} 
& \text { Table } 1 & \\
& 1 & \\
& 1+ & \text { Rhesus type } & \text { Total } \\
\text { Articular disease } & 71 & 28 & 99 \\
\text { Normals (New York City) } & 902 & 160 & 1,071 \\
\qquad \chi^{2}\left(x^{2}=10 \cdot 12, P=c .\right. & 1.5 \times 10^{-3} . &
\end{array}
$$

28

This work was supported by grants $(H-1076(C 8))$, $(R G-6939(C 4))$, and $T 1 A M 5285(03))$ from the U.S. National Institutes of Health, and a research grant ( $N S F-$ $G-15082$ ) from the National Science Foundation. One of us (M. H.) is a trainee in human genetics under grant $H T S-5388$ from the National Heart Institute. Another (W. C. B.) is the recipient of a National Institutes of Health research career award (5-K6-GM-14, 184-02).

\section{Alan S. Cohen \\ WrLLIAM C. BOYd \\ SaNdra Goldwasser}

Edgar S. Cathcart

School of Medicine.

Boston University,

Harvard University.

\section{Mary Heisler}

${ }^{1}$ Wiener, A. S., and Gordon, E. B., Amer. J. Clin. Path., 19, 621 (1949). ${ }^{2}$ Boyd, W. C., Heisler, M., and Orowan, B., Nature, 190, 1123 (1961).

\section{Changes in the Concentration of Potassium in the Erythrocytes and in Hamoglobin Type in Merino Sheep under a Severe Anæmic Stress}

Most breeds of sheep are polymorphic with respect to the concentration of potassium in their erythrocytes (70-90 m.equiv. $\mathrm{K}^{+}(H K)$ or $10-20$ m.equiv. $\mathrm{K}^{+}(L K)$ per litre of red cells ${ }^{1}$ ) and hæmoglobin type ( $\mathrm{Hb} \mathrm{A}, \mathrm{B}$ or $\mathrm{AB}^{2}$ ). High concentrations of $\mathrm{K}^{+}$(approximately 110 m.equiv. /l.), which fall to normal adult levels 60-100 days after birth, are found in the erythrocytes of all foetal lambs ${ }^{3}$. In the erythrocytes of normal adult sheep the mean concentration of potassium remains relatively 